\title{
PENDIDIKAN KRISTEN YANG MENCERAHKAN
}

\section{Aeron Frior Sihombing}

\section{ABSTRAK}

Pendidikan yang mencerahkan bukanlah pendidikan yang bersifat dogmatis, sehingga memenjarakan peserta didik di dalam ideologi dan sistem yang tertutup. Pendidikan juga bukan sebatas untuk menjadikan seseorang terampil dalam bekerja, sehingga ia menjadi budak sistem. Akan tetapi, pendidikan seharusnya memanusiakan manusia menjadi manusia, membebaskan dan melepaskan peserta didik dari penindasan, kemiskinan, penjajahan, ideologi/sistem tertutup. Inilah yang disebut sebagai pendidikan mencerahkan.

\section{Kata kunci: Pendidikan, mencerahkan, kemanusiaan, penindasan.}

\section{PENDAHULUAN}

Selama ini, pendidikan yang penulis ikuti mulai dari sekolah dasar sampai ke perpendidikan tinggi kecenderungannya (meskipun tidak semua) adalah pendidikan yang menghafal. Murid harus mengikuti apa yang diinginkan oleh sang pendidik, di mana pendidik hanya menginginkan murid untuk mengerti dan memahami mereka, sesuai dengan selera pendidik itu sendiri. ${ }^{1}$

Selain itu, pendidikan juga dirancang hanya untuk kepentingan para penguasa, pengusaha, pemerintah. Tujuannya adalah agar murid dapat bekerja, sehingga yang hanya dipentingkan adalah keterampilan atau skillnya. Dengan demikian setelah lulus, ia akan dapat masuk ke dalam dunia kerja. Jadi, pendidikan tersebut hanya untuk kepentingan eksternal, yaitu dunia kerja. Dampaknya adalah

1 Nicholas P. Wolterstorff, Mendidik untuk Kehidupan. Lana Asali (terj), (Surabaya: Momentum, 2002), 7. 
para murid dibentuk seperti robot, yaitu diprogram hanya untuk mengikuti program dari sang pendidik maupun sekolah. Tanpa disadari, telah terjadi dehumanisasi manusia.

Oleh sebab itu dalam tulisan ini, penulis ingin mengungkapkan bagaimanakah pendidikan Kristen itu yang sebenarnya, yaitu suatu pendidikan yang mencerahkan manusia. Menjadikan manusia menjadi manusia, di mana ini merupakan suatu bagian pendidikan yang harus diperjuangkan.

\section{Fondasi Kehendak Allah di dalam Pendidikan}

Fondasi dari pendidikan Kristen yang mencerahkan adalah Yesus Kristus itu sendiri. Sebab, Yesus merupakan model, contoh, teladan dari seluruh kehidupan orang Kristen. Semua perkataan, ajaran, perbuatan, tindakan dan juga kehidupan Yesus merupakan landasan hidup orang Kristen. ${ }^{2}$ Sebab, perkataan, ajaran dan perbuatan atau tindakan Yesus tidak dapat dipisahkan satu dengan yang lain. Mereka adalah suatu kesatuan yang tidak dapat dipisahkan, sebab ajaran atau perkataan Yesus dipraksiskan di dalam tindakan Yesus, sehingga menjadi konkret. ${ }^{3}$ Demikian juga dengan tindakan atau perbuatan Yesus, merupakan penjabaran dari perkataan dan ajaran Yesus. Pengajaran Yesus adalah konkret dan aplikatif. Tidak boleh juga dilupakan yaitu kehidupan Yesus, baik kelahiran, penderitaan, kematian dan kebangkitan Yesus juga adalah suatu kesatuan yang tidak boleh untuk dipisahkan. Ini merupakan bagian penting di dalam Kekristenan dan semuanya memiliki makna di dalam Kekristenan. Kedatangan Yesus Kristus ke dunia ini adalah untuk menjalankan misi, yaitu untuk melakukan kehendak Allah. ${ }^{4}$

Gereja yang beriman kepada Yesus harus mengikuti dan bersandar kepada Yesus. ${ }^{5}$ Ia harus mengikuti ajaran/perkataan dan

${ }^{2}$ Hans Kung, On Being A Christian (New York: Double\&Company, 1974), 463-466.

${ }^{3}$ Ibid.

${ }^{4}$ Ibid.

${ }^{5}$ Hans Kung, The Church (New York: Sheed and Ward, 1967), 71-78. 
tindakan/perbuatan Yesus. Hal inilah yang menjadi keistimewaan orang Kristen, yaitu Yesus itu sendiri. Ia menjadi seorang pengikut Yesus dan mau mati bagi-Nya.

Inilah yang menjadi dasar atau fondasi dari kehendak Allah di dalam pendidikan Kristen yang mencerahkan. Dengan demikian, pendidikan yang mencerahkan ini harus dilakukan oleh Gereja yaitu untuk melakukan kehendak Allah. Pertanyaannya adalah apakah kehendak Allah dalam pendidikan yang mencerahkan tersebut?

\section{Kebaikan atau kesejahteraan manusia}

Kehendak Allah bagi manusia adalah untuk kebaikan manusia itu sendiri. Sebab, inilah yang dilakukan oleh Yesus ketika datang ke dunia. Hal ini dapat terlihat dari semua perkataan, ajaran, tindakan/perbuatan dan kehidupan (kelahiran, penderitaan, kematian, kebangkitan) Yesus tersebut adalah: untuk membebaskan manusia: ${ }^{6}$

Untuk membebaskan manusia dari maut, kematian yang kekal, sebab dosa yang telah diakibatkan oleh Adam. Yesus tersalib untuk menebus dan memerdekakan manusia dari penindasan dosa. Pemenuhannya atau kesempurnaannya adalah pada waktu kedatangan Yesus yang kedua kali;

Yesus juga melepaskan manusia dari perbudakan, penindasan dari sistem pemerintahan yang menindas, maupun sistem keagamaan legalis yang menindas manusia. Hal ini telah ditunjukkan oleh Yesus ketika melawan pemerintah yang semena-mena, dengan mengatakan bahwa seorang penguasa haruslah melayani orang yang dipimpinnya. Yesus juga melawan sistem keagamaan Yahudi yang legalis, yang lebih mementingkan hukum legal, dari pada firman Allah yang membebaskan dan yang berdasarkan kasih; Yesus juga membebaskan orang yang menderita, yang mana Yesus mengatakan

${ }^{6}$ Kung, On Being A Christian, 117-211. 
bahwa orang yang percaya kepada-Nya akan dapat menanggung penderitaan, karena salib. Yesus mengatakan bahwa berbahagialah orang yang menderita karena Allah; ${ }^{7}$

Yesus juga melepaskan orang dari kemiskinan baik secara sosial maupun rohani. Hal ini dapat terlihat, ketika Yesus memberi makan 5000 orang yang kelaparan, karena mengikuti-Nya. Yesus juga menyembuhkan orang-orang yang sakit, seperti lumpuh, kusta, pendarahan, bisu, tuli, kerasukan; Yesus juga menerima orang-orang yang dianggap berdosa (karena tidak melakukan hukum Taurat), najis, tidak dapat diampuni lagi oleh para elit agama Yahudi, seperti imam, ahli Taurar, Farisi, Saduki. Mereka itu adalah perempuan pelacur, pemungut cukai, orang penyakit kusta dan lainnya. Mereka dibebaskan dan dimerdekakan oleh Yesus dan masuk ke dalam Kerajaan Allah. ${ }^{8}$

Ini adalah isi berita Kerajaan Allah yang diberitakan oleh Yesus di dalam ajaran, perkataan, tindakan/perbuatan dan kehidupan Yesus. Dia datang untuk membebaskan dan memerdekakan manusia. Inilah kehendak Allah yaitu kebaikan/man's well being. Oleh karena itu, sisi humanitas/kemanusiaan sangat penting untuk diperhatikan. Sebab, kehendak Allah adalah untuk kebaikan manusia/man's well being.'

Hal ini banyak diabaikan oleh pendidikan, di mana pendidikan hanya diarahkan hanya untuk bagaimana menghafal, ${ }^{10}$ dogmatisasi yang membabi buta maupun ideologisasi, sehingga muncullah ekstremis yang menghancurkan, hanya untuk menajamkan skill atau keterampilan untuk bekerja, informasi pengetahuan, memeroleh gelar atau ijazah, pendidikan hanya untuk kepentingan penguasa.

Inilah tugas dan panggilan Gereja maupun institusi Kristen (sekolah Kristen, seminari atau sekolah tinggi teologi) untuk
${ }^{7}$ Ibid, 117-211.
${ }^{8}$ Ibid, 192-200.
${ }_{9}^{9}$ Ibid, 249-273.
10 Wolterstorff, Mendidik untuk Kehidupan, ... 7. 
melayani manusia yang membutuhkan dengan kasih, yang dilakukan melalui pendidikan yang mencerahkan, di mana kurikulum pendidikan ini berisikan pembebasan manusia. Bagaimana memajukan manusia yang terbelakang dan memanusiakan manusia yang telah tertindas, terbelakang. Maka, Gereja harus mengikuti Yesus Kristus dan melakukan kehendak Allah, yang memerjuangkan kebaikan manusia/man's well being. Semuanya harus dilakukan berdasarkan kasih, yang dilandasi oleh kasih Allah dan kasih terhadap sesama manusia: yaitu orang yang membutuhkan, seperti orang yang miskin, tertindas, menderita. Kasih ini adalah kasih yang tanpa syarat dan kasih yang tidak meminta imbalan atau jasa dari orang yang menerimanya.

\section{Proklamasi Injil dan Nilai-Nilai Kerajaan Allah}

Di sisi lain juga, pendidikan Kristen yang mencerahkan adalah pemberitaan atau perwartaan juga sangat penting untuk dilakukan, karena ini juga adalah kehendak Allah yang harus dilakukan. Sebab melalui pemberitaan Injil ini, maka peserta didik dapat berjumpa dengan Allah, sehingga mereka diubahkan dan dicerahkan oleh Roh Kudus yang akan menuntun mereka. Ini menjadi satu paket dengan bagaimana menyejahterakan manusia dari sisi ekonomi dan sosiologisnya. Sebab, proklamasi atau perwartaan Injil adalah tugas yang penting dan esensi bagi pendidikan Kristen yang mencerahkan. ${ }^{11}$

Hal ini disertai dengan menegakkan nilai-nilai Kerajaan Allah di Indonesia, yaitu: keadilan, kebenaran, kekudusan, pengampunan dan perdamaian. Pendidikan harus mengajarkan dan menekankan dalam kehidupan murid atau peserta didik yaitu keadilan dan kebenaran. Mereka harus mengerti dan memahami apa itu keadilan dan kebenaran, di mana ini dapat terwujud di dalam penegakan hukum oleh negara. Oleh sebab itu, hal ini harus ditanamkan di

${ }^{11}$ Kung, The Church, ... 339. 
dalam diri peserta didik. Kemudian, kekudusan di dalam kehidupan murid, baik kehidupan pribadi, keluarga, bermasyarakat, di dalam pendidikannya, bergereja, pekerjaan, harus diajarkan, sehingga mereka memiliki moralitas, karakter, tingkah laku yang sesuai dengan Kristus. Pengampunan dan perdamaian merupakan hal yang berdampingan, di mana para peserta didik harus diajarkan agar mereka belajar untuk mengampuni orang yang bersalah kepadanya, bahkan musuhnya sekalipun, sehingga dapat terjadi perdamaian diantara sesama manusia.

Hal ini merupakan suatu fondasi penting dalam pendidikan Kristen, sehingga apabila ini dilakukan, maka pendidikan yang diterima oleh para peserta didik, akan terjadi pencerahan. Hal ini akan mengubah kehidupan para murid-peserta didik, sehingga akan sama seperti Kristus, yang datang ke dunia untuk mencerahkan manusia, serta melepaskan, membebaskan dan menyelamatkan manusia.

\section{Apakah pendidikan dapat memberikan pencerahan}

Pendidikan yang mencerahkan tersebut adalah pembebasan dari rasisime. Paulo Freire dalam Grant S.Shockley ${ }^{12}$ mengatakan bahwa: There is no such thing as neutral education. Education is either for liberation or againts liberation and therefore in favor of domination. Pendidikan haruslah membebaskan dari belenggu rasisme. Fondasinya adalah Yesus Kristus sebagai seorang pembebas. Maka, pendidikan itu harus dapat membebaskan dan melepaskan peserta didik dari belenggu rasis, sehingga terjadi kesetaraan manusia.

Manusia adalah sama di hadapan hukum, undang-undang, maupun masyarakat dan kedudukan mereka sama di mata hukum. Dengan demikian, di dalam pendidikan harus menekankan dan mengajarkan bahwa rasisme itu tidak diizinkan dan diperbolehkan di Indonesia. Apakah itu adalah rasis karena suku, agama, status sosial,

12 Grant S. Shockley, "Liberation Theology, Black Theology, And Religious Education" di dalam Foundations for Christian Education in an Era of Change, (ed) Marvin J.Taylor (Nashville: Abingdon, 1976),80-81. 
pekerjaan dan yang lainnya. Pendidikan inilah yang akan mencerahkan manusia.

\section{Belenggu dogmatisme/ideologi}

Hal yang paling menakutkan dalam pendidikan adalah dogmatisme atau doktrinisasi pendidik kepada murid. Hal inilah yang menyebabkan ekstremisme dan fundamenalisme dalam agamaagama di Indonesia yang beraliran keras. Mereka mau mati dengan cara bom bunuh diri, agar masuk surga. Hal ini dilakukan, sebab ini dianggap sebagai sesuatu yang baik dan mulia, yang dilakukan demi agama.

Demikian halnya juga di sekolah-sekolah, kebanyakan para pendidik mengajarkan kepada peserta didiknya agar mengikuti semua pandangan dan ajarannya secara membabi-buta, tanpa dipikirkan secara kritis. ${ }^{13}$ Sebab, pendidik / pendidik dianggap sebagai orang yang paling benar, bahkan dianggap sebagai ukuran dari kebenaran itu sendiri, sehingga terjebak dalam dogmatisme atau doktrinisasi.

Hal ini merupakan sesuatu yang berbahaya, oleh sebab itu pendidikan haruslah membuka wawasan para peserta didik, di mana mereka diajar untuk bersikap kritis, dan mereka diajar untuk menemukan kebenaran itu sendiri. Oleh sebab itu, research/penelitian haruslah diajarkan kepada para peserta didik dan ini merupakan jantung dari pendidikan itu sendiri, sehingga mereka diajar untuk dapat menemukan kebenaran itu sendiri, tanpa tergantung kepada pendidik/pendidiknya. Pendidik/pendidik hanya sebagai pembimbing dan fasilitator dari peserta didiknya.

Dengan demikian, pendidikan ini akan mencerahkan para peserta didik. Mereka akan menemukan kebenaran itu sendiri, research menjadi bagian dari hidupnya, ia akan berpikir secara kritis, dan pikirannya akan terbuka, sehingga mereka menjadi orang yang bebas

${ }^{13}$ Wolterstorff, Mendidik untuk Kehidupan, ..., 7. 
dan merdeka. Maka, pendidikan ini adalah berbasiskan manusia atau peserta didik itu sendiri.

\section{Kemiskinan}

Pendidikan bukan hanya untuk menambah pengetahuan, tetapi juga untuk meningkatkan kehidupan para peserta didik, melalui kemampuan atau skill yang mereka miliki. Peserta didik yang tadinya biasa, menjadi luar biasa; mereka yang tadinya tidak mampu, menjadi mampu; yang tadinya tidak dapat hidup mandiri dan menghidupi dirinya sendiri, sekarang ia dapat mandiri dan mencukupi segala kebutuhannya; yang tadinya kurang mampu atau miskin, dapat menjadi kaya, karena pendidikan yang mereka miliki.

\section{Kebodohan}

Pendidikan juga membebaskan manusia dari ketidaktahuan dan kebodohan menjadi tahu dan menjadi lebih pintar. Ia dapat menguasai ilmu pengetahuan, sehingga ia dapat hidup atau survive dan juga dapat tercerahkan dari ketidaktahuannya. Melalui pendidikan, manusia seharusnya sadar, bahwa ia tahu kalau ia tidak tahu seperti yang diungkapkan oleh Socrates. Dengan kesadaran seperti ini, maka manusia akan tahu akan kelemahannya dan kebodohannya, sehingga ia menjadi manusia yang bijaksana dan berhikmat.

Hal inilah yang terpenting dalam pendidikan, yaitu mencerahkan manusia dari ketidaktahuan dan kebodohannya, sehingga ia menjadi manusia yang bijaksana dan berhikmat sebagai seorang manusia. Maka, ia akan menjadi manusia yang dewasa, tidak tergantung sesuatu di luar dari dirinya, kecuali hanya bergantung kepada Allah. Ini sama seperti seseorang yang sedang diterangi oleh cahaya lampu di tengah malam, demikian pendidikan yang memberi penerangan dan pecerahan, sehingga ia berjalan dalam dunia yang gelap. 


\section{DAMPAK PENDIDIKAN KRISTEN YANG MEMBEBASKAN}

\section{Memanusiakan manusia menjadi manusia/humanisme}

Pendidikan yang mencerahkan itu adalah pendidikan memanusiakan manusia menjadi manusia, yaitu dengan mengajarkan hak asasi manusia. Hal yang penting diajarkan adalah menghormati kemerdekaan, persamaan/kesederajatan, persaudaraan dan martabat manusia. Bagi Kung, dasar dari humanisme ini adalah martabat manusia itu sendiri dan ini merupakan hak dasar manusia ${ }^{14}$. Martabat manusia itu adalah hak-haknya sebagai manusia harus diperjuangkan, seperti kemerdekaan, kebebasan untuk hidup, hak beragama, berbicara ${ }^{15}$, pengakuan kesatuan keluarga manusia, yaitu persamaan dan martabat semua laki-laki dan perempuan, pentingnya dan kudusnya individu dan kesadarannya, iman dalam kasih, simpati, tidak mementingkan diri sendiri dan kuasa kebenaran dalam pikiran dan dalam hati lebih besar kuasanya dari pada kebencian, permusuhan dan kepentingan diri sendiri, kewajiban membantu orang yang miskin, tertindas, orang terpinggirkan, dan melawan orang kaya dan penguasa yang menindas orang miskin dan terpinggirkan, serta pengharapan yang dalam atas kemenangan kehendak yang baik ${ }^{16}$.

Hal ini merupakan suatu nilai-nilai universal di seluruh dunia ${ }^{17}$, di mana ini sesuatu yang sangat diiinginkan dan dibutuhkan oleh manusia. Nilai-nilai kemanusiaan atau humanisme ini ada di dalam seluruh agama di dunia ini dan ini merupakan bagian yang sangat

14 Di kutip dari tugas paper Aeron F. Sihombing dalam konsentrasi II “Pluralisme Menurut Hans Kung” (Cipanas: STT Cipanas, 2013), 13.

${ }^{15}$ Ibid, 89-90.

16 Hans Kung, Theology for the Third Millenium An Ecumenical View (New York: Double, 1988), 243.

${ }^{17}$ Ibid, 240-247. 
penting dalam pendidikan. Sebab, salah satu tujuan dari pendidikan yang mencerahkan adalah untuk melayani kemanusiaan atau humanitas, sehingga manusia dapat menemukan tujuan hidup, kebahagiaan dan eksistensi dirinya menghasilkan buah.

Jadi, kemanusiaan merupakan salah satu bagian penting dari pendidikan maupun agama yang baik ${ }^{18}$, di mana ini merupakan ciri dan ukuran pendidikan yang benar, yang memerjuangkan martabat manusia, selain itu adalah agama yang tidak benar dan patut untuk dipertanyakan. Martabat manusia merupakan nilai-nilai yang sangat penting dalam pendidikan, secara khususnya adalah pendidikan Kristen di Indonesia ${ }^{19}$.

\section{Meningkatkan spiritualitas}

Dampak yang penting dalam pendidikan yang mencerahkan ini adalah meningkatkan spiritualitas, dan bukan hanya kognitif, skill atau keahlian tertentu, sehingga dapat bekerja. Akan tetapi, peningkatan spiritualitas, yaitu menjadikan peserta didik menjadi seorang manusia yang lebih bijaksana dan berhikmat dalam menghadapi segala persoalan dan permasalahan yang dihadapi dalam kehidupan sehari-hari.

Di samping itu, peserta didik akan memiliki kesadaran di dalam hidupnya, yaitu suatu kesadaran bahwa ia adalah seorang

\section{${ }^{18}$ Ibid, 92.}

19 Secara teologis, manusia adalah ciptaan serta gambar dan rupa Allah. Manusia memiliki martabat, kehormatan, hak dan kewajiban di hadapan Allah. Manusia sangat berharga di hadapan Allah, sehingga Allah membebaskan dan memerdekakan manusia dari dosa, melalui salib. Hal inilah yang menjadikan mengapa Kekristenan sangat memerjuangkan bumanum. Manusia adalah makhluk yang bebas, dan dapat memilih apa yang menjadi pilihannya. Akan tetapi bagi Hans Kung, manusia adalah man's theonomy yaitu berdiri sendiri dengan akal dan pikirannya, akan tetapi ia bergantung kepada Allah. Ia tidak hidup otonomi, tanpa Allah, sebab bila hidup tanpa Allah hidupnya menjadi tidak berarti dan nihil. Dengan demikian, agama menjadi tempat di mana manusia akan memeroleh makna. Di sinilah letak man's theonomi manusia. 
manusia yang sangat berharga di mata Allah, suatu kesadaran bahwa ia tahu, kalau ia tidak tahu, suatu kesadaran bahwa ia adalah seorang manusia yang bermartabat, yang memiliki hak dan kewajiban di dalam kehidupan ini. Kesadaran juga bahwa ia seorang manusia yang tidak dapat berdiri sendiri, tanpa adanya Allah yang menopangnya. Hal inilah spiritualitas dari pendidikan Kristen yang mencerahkan.

\section{Perjumpaan Eksistensialis dengan Yesus}

Manusia hanya dapat dicerahkan ketika ia berjumpa dengan Yesus. ${ }^{20}$ Sebab, hal ini merupakan bagian dan tujuan yang sangat penting dalam pendidikan Kristen yang mencerahkan. Tujuan pendidikan itu adalah bagaimana seseorang dapat berjumpa secara pribadi dengan Yesus Kristus, sehingga ia mengalami perubahan dalam kehidupan. Maka, ia akan menyadari bahwa ia adalah manusia gambar dan rupa Allah, yang memiliki martabat, dan juga hak asasi sebagai manusia.

Oleh sebab itu, Robert W. Pamino ${ }^{21}$ mengatakan bahwa perjumpaan dengan Yesus tersebut akan membawa pertobatan yang sejati, sehingga hidup peserta didik akan berubah (Efesus 2:1-9); kekudusan atau kesucian hidup; dan kesalehan diri dari peserta didik, baik secara pribadi maupun sosial. Hal inilah yang akan mengubah kehidupan seorang peserta didik, sehingga pendidikan ini mencerahkan.

\section{Meningkatkan mutu kehidupan manusia}

Dampak selanjutnya dari pendidikan Kristen yang mencerahkan adalah meningkatkan mutu kehidupan, sebab ini merupakan fondasi dari pendidikan yang harus diperjuangkan oleh

20 Karl Barth, Pengantar ke dalam Teologi Berdasarkan Injil (Jakarta: BPK Gunung Mulia, 2012), 17-48.

21 Robert W. Pazmino, Foundational Issues in Christian Education (Grand Rapids: Baker Book House, 1997), 56-66. 
orang Kristen. Kehidupan manusia tidak boleh stagnasi, akan tetapi mutu dan kualitasnya harus ditingkatkan, seperti yang diungkapkan di dalam teori pendidikan yang mencerahkan di atas bahwa manusia yang dahulu adalah miskin maupun menengah ke bawah, sekarang dapat naik menjadi menengah ke atas, dan ia mampu untuk menghidupi kehidupannya sehari-hari. Di samping itu, ia juga akan memiliki pengetahuan yang akan membawanya dari pembebasan dari orang-orang yang akan menyalahgunakannya atau yang membodohinya.

Hal inilah yang menjadi kegunaan teori yang dihasilkan oleh pendidikan yang mencerahkan itu, yaitu: ${ }^{22}$ 1) penelitian, di mana teori pendidikan akan menyediakan dasar dan konteks untuk penelitian, sehingga ia akan menguji teori dan pengetahuan yang ada, maka ia tidak terjebak ke dalam dogmatisme atau doktrinisasi yang sempit; 2) kebijakan dalam mengambil keputusan. Hal inilah manfaat dari pendidikan, yaitu akan membantu untuk mengambil keputusan dalam berbagai masalah yang akan dihadapi; 3) perencanaan, di mana melalui teori yang diperoleh melalui pendidikan akan dapat digunakan untuk membuat rancangan atau rencana dari hari ke hari, bahkan rencana untuk masa depan dari peserta didik. Oleh sebab itu, ia akan menjadi manusia yang mandiri, karena kualitas hidup melalui pendidikan yang dimilikinya telah mencerahkan dan membebaskan dirinya dari cengkraman apa pun yang telah melandanya.

22Teori dalam pendidikan Kristen seharusnya adalah: bermanfaat/ berguna. Teori berguna untuk memberitahukan apa yang seharusnya kita lakukan dan perbuat di dalam kehidupan. Sebab tanpa hal itu, kita tidak akan dapat melakukan apa pun atas data yang miliki. Teori juga memberitahukan dan mengunakan data yang telah ada, apakah dia relevan pada saat ini atau tidak relevan dalam kehidupan ini. Hal ini akan membawa kita untuk mengerti apa yang harus kita lakukan dan apa yang seharusnya tidak kita lakukan. Dengan demikian, ini akan dapat membuat kita menjadi bijaksana atau berhikmat di dalam kehidupan ini. (Charles F. Melchert, "Theory In Religious Education," di dalam Foundations for Christian Education in an Era of Change, (ed) Marvin J.Taylor (Nashville: Abingdon, 1976), 23-25. 


\section{Bagaimanakah pendidikan dapat mencerahkan:}

Pendidikan yang dapat mencerahkan itu adalah: ${ }^{23}$ 1) terbuka terhadap segala bentuk pandangan, teori, maupun pengetahuan dan tidak langsung menutup diri, apabila ada sesuatu yang baru. Ia tidak boleh tertutup dan merasa bahwa dirinya yang paling benar dan yang lain adalah salah. Dengan kata lain, pendidikan tidak boleh terjebak di dalam absolutisme, sebab akan terjebak dalam ekstremisme dan akan menganggap yang lain salah. Inilah yang disebut dengan ideologi permusuhan maupun pertentangan. Maka, manusia akan dibelenggu dan dipenjara oleh pemikiran yang sempit;

2) Terbuka terhadap respons kritik terhadap rumusan teorinya. Semangat dari pendidikan dan keilmuan adalah ia harus terbuka dan teorinya juga rela untuk dikritik, sebab tidak ada pengetahuan yang benar secara mutlak di dunia ini. Semuanya adalah mendekati kebenaran, kecuali hanya Allah sendiri yang benar. ${ }^{24}$ Maka, pendidikan haruslah mau untuk menerima kritikan dari orang lain terhadap dirinya sendiri. Sikap dan semangat seperti ini harus ditularkan kepada peserta didik di dalam sekolah maupun perpendidikan tinggi, dan ini harus diajarkan oleh pendidik/pendidik kepada peserta didiknya;

3) Rela belajar dari sumber yang tidak terduga. Semangat belajar harus ditularkan dari pendidikan, bahkan pelajaran maupun ilmu yang tidak terduga, ataupun yang tidak terpikirkan sebelumnya. Oleh sebab itu, sikap terbuka sangat dibutuhkan di sini. Hal ini bukan hanya oleh para peserta didik, tetapi juga pendidik harus memiliki rasa dan sikap terbuka terhadap pengetahuan. Dengan demikian, pendidikan tidak hanya terjadi pada saat sekolah maupun

${ }^{23}$ Ibid, 28-29.

24 Wolfhart Pannenberg, Theology and Philosophie of Science (Philadelphia: The Westminster Press, 1976), 166-155. 
kuliah, tetapi seumur hidup. Hal inilah yang seharusnya digalakkan di dalam pendidikan, sehingga semangat belajar dan ingin tahu ini akan mencerahkan manusia. Ini merupakan natur dari pendidikan itu sendiri;

4) Mendidik peserta didik menjadi seorang peneliti yang mandiri, sehingga mereka dapat menemukan pengetahuan sendiri, bahkan penemuan yang baru demi kepentingan umat manusia atau kemanusiaan. Dengan demikian, peserta didik tidak dididik hanya dengan hafalan dan mengikuti apa kata pengajar, tetapi ia berusaha untuk menemukan kebenaran maupun pengetahuan itu sendiri. Oleh sebab itu, tugas seorang pendidik/pendidik menjadi pembimbing, di mana peserta didik diberikan alat/tool untuk meneliti;

5) Sadar atas kelemahan dan keterbatasan manusia, dan karena itu pemahaman manusia adalah sangat terbatas terhadap para ahli teoretis, peneliti dan praktisi. Sebab, kejeniusan, kepintaran, kehebatan manusia adalah terbatas. Manusia hanya mengetahui hanya sebagian dari apa yang diteliti, dipelajari dari alam semesta ini. Jadi, pengetahuan manusia seperti setetes air di samudera raya. Ia hanya melihat sebagian kecil dari dunia ini. Oleh sebab itu, semakin seorang ilmuwan mengetahui sesuatu, maka semakin banyak hal yang tidak diketahui olehnya. Maka, ia akan semakin penasaran dan ingin tahu, dan semakin ia akan terus mencari. Inilah keterbatasan dari pengetahuan manusia itu.

Kesadaran ini haruslah ditanamkan di dalam pendidikan, sehingga para peserta didik akan terus mencari pengetahuan dan akan terus belajar untuk kepentingan manusia dan pendidikan itu sendiri. Inilah hakikat dan natur pendidikan yang mencerahkan itu. Di samping itu, ia akan menyadari bahwa dirinya terbatas, sehingga ia akan terus rendah hati, dan menyadari kemahakuasaan Allah yang tidak terbatas.

Di samping itu, pendidikan seharusnya mengajar pengetahuan kepada peserta didik. Hal ini seperti yang dilakukan oleh Tuhan Yesus kepada para murid-Nya, sehingga para murid memeroleh pengetahuan yang benar mengenai Kerajaan Allah, firman Allah maupun apa yang Allah kehendaki dalam kehidupan mereka. 
Pengajaran akan pengetahuan akan membuka pikiran, wawasan, kesadaran, melatih pemikiran secara kritis dari peserta didik. Akibatnya adalah murid dan peserta didik akan dapat menganalisis dan juga dapat mengkritisi pemikiran dan teori yang ada, serta sebagai alat untuk mencari kebenaran. Inilah gunanya pengajaran akan pengetahuan.

Selanjutnya adalah mendidik dan bukan hanya pengetahuan (yang hanya mengasah kemampuan berpikir secara kritis dan analisis), sebab mendidik adalah untuk menjadikan karakter seorang peserta didik menjadi lebih baik dan matang. Mendidik akan menjadikan peserta didik memiliki moral dan etika yang sesuai dengan firman Allah. Hal ini juga dilakukan oleh Yesus Kristus kepada murid-murid-Nya, di mana Ia mendidik karakter dan moral para murid menjadi sama seperti-Nya, yang sesuai dengan kehendak Allah.

Selanjutnya adalah pelatihan. Teori atau pengajaran yang diberikan oleh Yesus kepada para murid-Nya langsung dipraktikkan di dalam lapangan. Tujuannya adalah untuk melatih skill/ kemampuan para murid. Misalnya adalah Tuhan Yesus mengutus para murid berdua-dua untuk memberitakan Injil kepada orang banyak. Jadi, ada praktik yang dilakukan untuk mengaplikasikan pengajaran yang telah diperoleh. Demikian juga dengan pendidikan Kristen, seharusnya adalah melatih skill atau kemampuan para peserta didik untuk mempraktikkan teori maupun pengajaran yang mereka terima, sehingga pendidikan tersebut menjadi hidup di dalam hidupnya. Dengan demikian, ia akan dapat terjun ke masyarakat untuk bekerja, berkarya dan mengabdi ke masyarakat maupun kepada Gereja untuk memuliakan Allah. Di samping itu, untuk meningkatkan kualitas hidupnya, dan juga agar dia dapat bertahan hidup di dalam dunia.

Jadi, pendidikan Kristen tersebut terdapat kesatuan antara pengajaran atau teori, pendidikan secara moral, karakter dan etika, 
serta skill/kemampuan atau keterampilan. ${ }^{25}$ Semuanya ini tidak dapat dipisahkan satu dengan yang lainnya. Ini merupakan fondasi atau dasar teologis secara biblika dari pendidikan. Apabila ini dilakukan di dalam pendidikan Kristen dalam segala bidang ilmu, maka pendidikan tersebut akan mencerahkan.

\section{KESIMPULAN}

Pendidikan Kristen (dalam segala bidang ilmu) yang mencerahkan bukanlah pendidikan yang mendogmatisasi, doktrinasi para peserta didik, sehingga ia akan memenjarakan pikiran mereka. Bukan juga hanya sebatas skill, yang hanya untuk mencari pekerjaan, dan juga bukan hanya mencari ilmu.

Akan tetapi, pendidikan Kristen tersebut adalah memanusiakan manusia menjadi manusia, yang menekankan hak asasi dan harkat martabat peserta didik sebagai manusia, menekankan kesejahteraan manusia untuk menjadi lebih baik lagi, sehingga ia terbebas dari segala bentuk penindasan, kemiskinan, kebodohan.

Fondasinya adalah Yesus Kristus, yang mengajar yaitu pengetahuan, mendidik yaitu karakter, moral dan etikanya yang dibina, serta pelatihan, yaitu untuk mengasah skill atau keterampilan/ kemampuan dari murid. Hal inilah yang harus dilakukan, sehingga para peserta didik akan memiliki pengetahuan, karakter, iman dan skill/keterampilan untuk meningkatkan mutu atau kualitas dari kehidupan. Dalam pendidikan ini, peserta didik diajar untuk bersikap terbuka terhadap ilmu, pengetahuan baru, dan tidak merasa dirinya paling benar, dan rela untuk dikritis, serta sadar bahwa kapasitas pikiran atau otak manusia adalah terbatas. Dengan demikian, ia harus rendah hati dan bergantung kepada Allah. Oleh sebab itu, pendidikan Kristen ini akan mencerahkan peserta didik. Semuanya ini adalah untuk kemajuan dan kesejahteraan peserta didik, serta untuk kemuliaan Allah.

25 Richard A. Muller, The Study of Theology (Grand Rapids: Zondervan Publishing House, 1991), 171-201. 
AERON FRIOR SIHOMBING, adalah pendidik STT SAPPI, mengajar Filsfat Kristen dan Teologi Reformed. Sarjana Teologi (S.Th) dari STT INTI Bandung pada tahun 2004; M.Div dari STT Bandung 2011. Gelar M.Th diperolehnya dari STT Cipanas dengan jurusan Etika-Biblika dari tahun 2015. 